\title{
Practical Application of the Results for Optically Measured Total Suspended Solids Concentrations in the Drava River
}

\author{
Bojana Dolinar \\ University of Maribor, Faculty of Civil Engineering, Maribor, Slovenia \\ Email: bojana.dolinar@um.si
}

Received 20 March 2014; revised 21 April 2014; accepted 12 May 2014

Copyright (C) 2014 by author and Scientific Research Publishing Inc. This work is licensed under the Creative Commons Attribution International License (CC BY). http://creativecommons.org/licenses/by/4.0/

(c) (i) 0 pen Access

\begin{abstract}
The investigations described in this paper were performed in order to determine whether the concentrations of total suspended solids (TSS) in the Drava River, Slovenia, measured indirectly with optical sensors can be used to determine the amount and particle size of the suspended solids that can settle in stagnant water. The possibility of continuous monitoring of the TSS concentrations would allow a more reliable estimate of the amount of sediment in the accumulation lake of the planned, pumped-storage, hydroelectric power plant into which the water from the Drava River will be pumped. Therefore, during a period of one year, 90 water samples were taken directly at the optical sensors. The amount of sediments and their mineral and chemical compositions were investigated, and particle size analyses were made in 15 samples. Microbiological parameters, which included a determination of the amount of phytoplankton, zooplankton, bacteria, fungi and organic debris, were investigated in all the water samples, and the temperature and $\mathrm{pH}$ of the water were measured at the time when the samples were collected. The comparison of the parameters examined with the TSS concentrations showed that these concentrations can serve as a very good estimate of the amount of particles settled in the standing water, as well as of their size. These correlations are clearly expressed in the cases where the amounts of phytoplankton and organic debris in the water are low.
\end{abstract}

\section{Keywords}

Suspended Solids, TSS Concentrations, Optical Sensors, Particle Size Distribution, Microorganisms

\section{Introduction}

The content of suspended solids in streams can be determined directly from samples of water or indirectly from 
data obtained using different measuring instruments that transmit and receive mechanical or electromagnetic waves. The list of measuring instruments includes optical sensors, which either measure part of the visible light transmitted through the water in a straight line between the light source and the light receiver or part of the visible or infrared light that is reflected and scattered (usually at an angle of $90^{\circ}$ with respect to a light source) to the receiver of the reflected light. In this way, in both cases, the turbidity of the water or the concentration of the total suspended solids (TSS) is determined. However, the amount of the latter can only be estimated, since the suspended particles in different waters can vary greatly, both in their composition and size, which influence the scattering, absorption and transmission of light, and so can affect the results of the measurements. Optical sensors must therefore be calibrated by using samples taken at various points of the measurement [1]-[7].

This paper presents the results of investigations of suspended solids in the Drava River, the most important Slovenian river for the production of electricity, with a length of $133 \mathrm{~km}$, a fall of $148.3 \mathrm{~m}$, and a mean annual flow of $297 \mathrm{~m}^{3} / \mathrm{s}$. On the Drava River there are eight hydroelectric power plants and four small hydropower plants, which together produce 25\% of the electricity in Slovenia. In 2012, the HACH-SOLITAX ts-line sc optical sensors were mounted at the hydropower plants Dravograd, Vuzenica and Mariborski otok (Figure 1). These sensors can measure turbidity in the range 0.001 to $4000 \mathrm{FNU}$ or TSS concentrations in the range 0.001 to $50 \mathrm{~g} / \mathrm{l}$. The data are recorded automatically at intervals of five minutes. In the studied case, the measurement results are expressed as TSS concentrations in mg/l, but for the reasons mentioned above they do not reflect the real values.

The pumped-storage hydroelectric power plant (PSPP) Kozjak is currently being planned for the Drava River. It will be located between the investigated locations of the HPP Vuzenica and the HPP Mariborski otok. The engine house will be located near the Drava River and the reservoir will be on the 700-m-higher plateau of the Kozjak Mountain (Figure 2). The upper water-storage reservoir will have a capacity of approximately 3,000,000 $\mathrm{m}^{3}$, and the total area of the bottom reservoir will be $107.511 \mathrm{~m}^{2}$. When the water is at a standstill the suspended particles will settle to the bottom of the reservoir; however, the amounts of sediment will depend on the operating mode of the PSPP and the concentration, the size and the composition of the suspended substances in the water while it is being pumped from the Drava River. The basic aim of our research was therefore to determine whether the data obtained using the optical sensors at these hydropower plants can be used to estimate the amount and the size of the suspended particles that can settle in the water. In addition to these interdependencies, various factors that may affect the results of the optical measuring instruments were also analysed, such as the content of organic debris, phytoplankton, zooplankton, bacteria and fungi, and the $\mathrm{pH}$ and temperature of the water.

\section{Methods of Investigations}

In order to cover the most diverse conditions, both in terms of the content of eroded materials and the occurrence of different organic substances in the river, water samples were taken during a period of one year, from

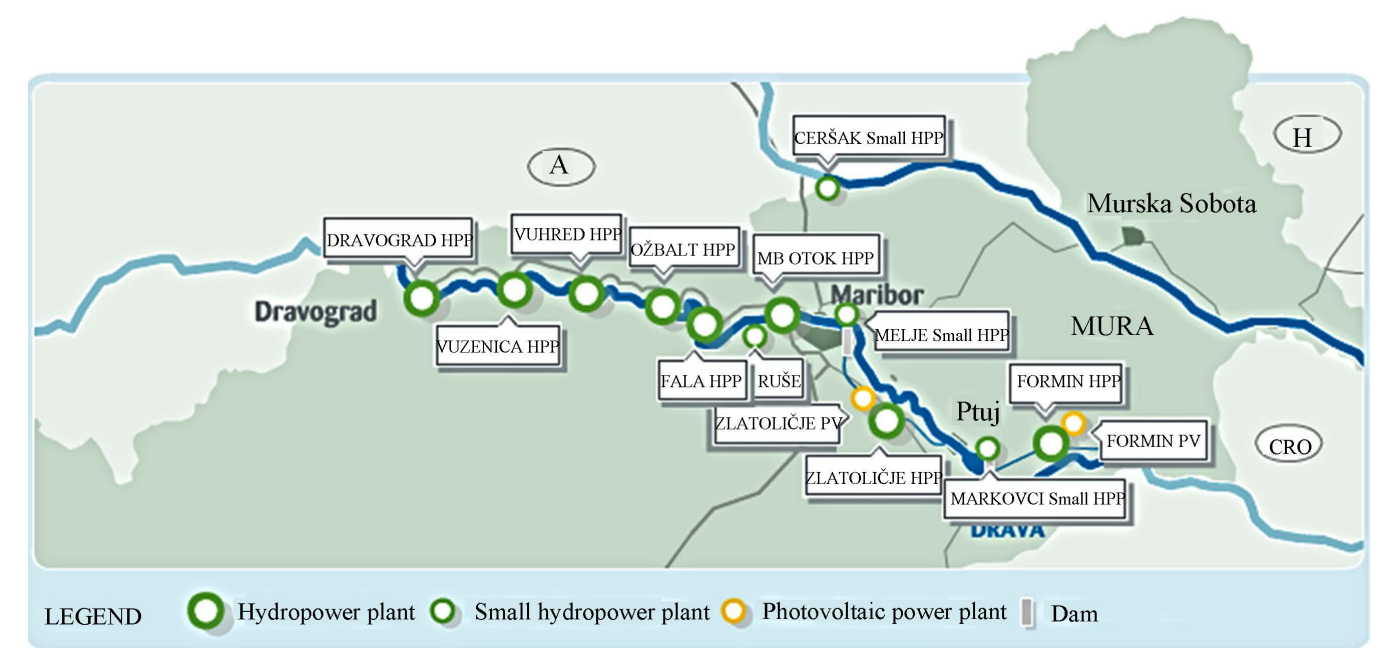

Figure 1. The locations of the optical sensors on the Drava River [8]. 


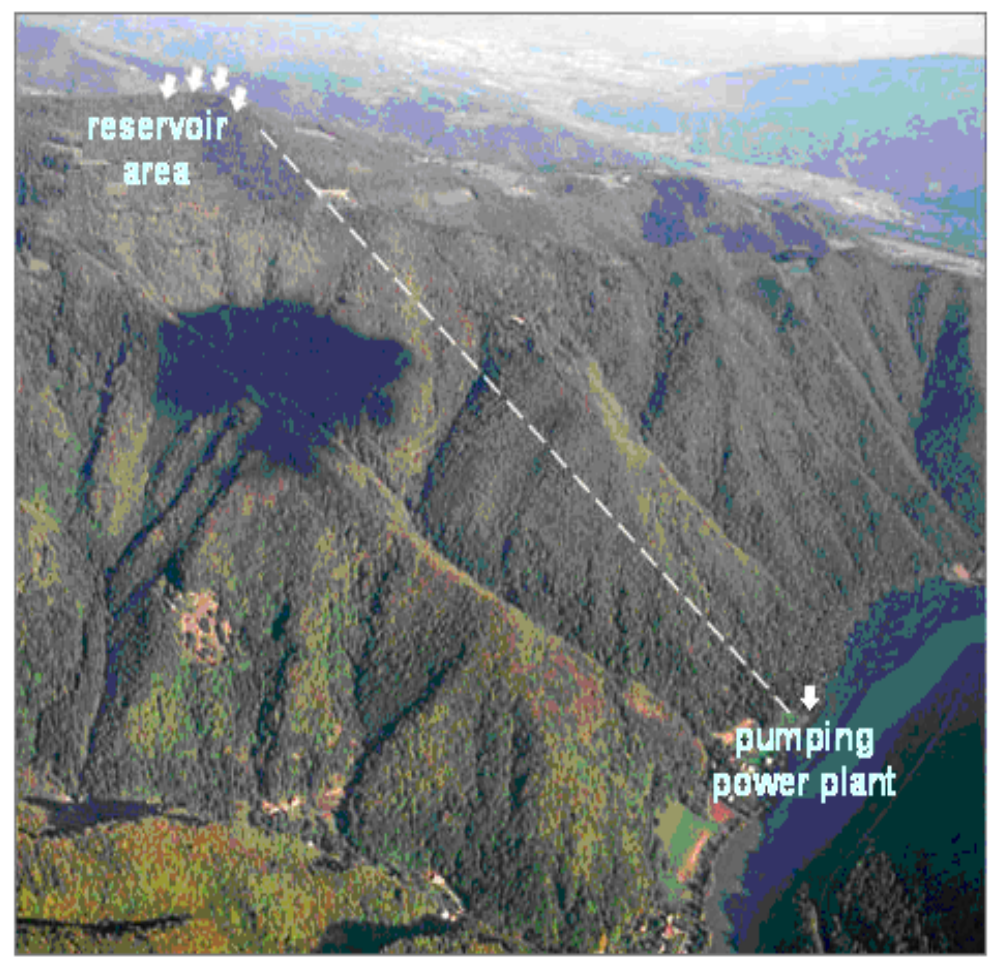

Figure 2. The location of the upper storage reservoir of the PSPP Kozjak [8].

August 2012 to July 2013. At all three locations, a total of 90 water samples were collected and, simultaneously, the air and water temperature were measured, the $\mathrm{pH}$ value, colour and odour of water were determined, and the visible dirt on the surface of the river was described.

Water samples were taken directly at the optical sensors at depths of 4 - $5 \mathrm{~m}$ using an isokinetic sampler. The amounts of sediments were determined in samples of 20 litres of water. Such large samples allowed more reliable results and the collection of larger quantities of sediments for their further investigation. Since the collecting of the samples took an average of 30 minutes, the mean value of the measurements carried out during this time was considered to be a valid reading for the in-situ-measured TSS concentrations.

\subsection{Determination of the Amount of Sediments}

For the purpose of this study the amount of suspended solids that settle in standing water was of particular interest; therefore, the laboratory investigation described below also had the same goal. In the selected procedure, the sediment was separated by means of a careful decantation of the water and by its evaporation in the final stage. Thus, a certain amount of sediment is marked in the text as SC, i.e., sediment concentration (mg/l). The time required for the settlement of the particles was selected according to the calculated speeds $v(\mathrm{~m} / \mathrm{s})$ of the sinking of particles using the Stokes Equation (1), where $\gamma_{S}$ and $\gamma_{W T}$ are the unit weight of the grains and the water, $D(\mathrm{~m})$ is the diameter of the spherical grains, and $\eta_{T}$ is the viscosity of the water at a selected temperature.

$$
v=\frac{\gamma_{S}-\gamma_{W T}}{18 \cdot \eta_{T}} \cdot D^{2}(\mathrm{~m} / \mathrm{s})
$$

The calculation took into account the average unit weight of the grains $\gamma_{S}=27 \mathrm{kN} / \mathrm{m}^{3}$ (depending on the density and the presence of the individual minerals in the composition), the unit weight of water at $20^{\circ} \mathrm{C}$ $\gamma_{W 20}=9.98 \mathrm{kN} / \mathrm{m}^{3}$ and the dynamic viscosity of the water at the same temperature $\eta_{20}=1.005 \times 10^{-3} \mathrm{~Pa} \cdot \mathrm{s}$. The calculations have shown that in five days all grains $\geq 0.0008 \mathrm{~mm}$ settle in a container with a height of $0.3 \mathrm{~m}$. It must be stressed that in practice the grains $<0.001 \mathrm{~mm}$ are very difficult to settle, except in those cases where flocculation occurs [9]. 


\subsection{Particle Size Analysis}

The particle size analyses of the sediments were performed by the Geological Survey of Slovenia using a laser particle sizer called "analysette 22"/Nano Tec, made by FRITSCH GmbH-Manufacturers of Laboratory Instruments, Germany. In total, 15 samples of sediments were tested at all three locations and selected for different TSS concentrations and amounts of micro-organisms and organic debris (Table 1).

\subsection{Mineralogical and Chemical Compositions}

The bulk mineralogy of the sediment was determined by the Geological Survey of Slovenia using X-ray diffraction techniques. The sample that was composed of different samples from the location of the HPP Mariborski otok was scanned using a Philips PW 3710 X-ray diffractometer with an 1820 goniometer, an automatic divergence slit, and a curved-crystal graphite monochromator. The instrument was operated at $40 \mathrm{kV}$ and $30 \mathrm{~mA}$ using $\mathrm{Cu}-\mathrm{K} \alpha$ radiation.

The chemical composition of the same sample was determined by Acma Analytical Laboratories Ltd., Vancouver. The inductively-coupled plasma emission spectrometry method was used to determine the main elements, quantitatively and qualitatively, whilst inductively-coupled plasma mass spectrometry was used to determine the trace elements. The amounts of carbon and sulphur were determined with a Leco CS444 element analyser. The results of the chemical analyses were used to check and confirm the quantities of the individual minerals in the sediment.

The optical microscope was used to investigate microscopic particles with a size of $20 \mu \mathrm{m}$ from the same sample, and a scanning electron microscope with an energy-dispersive X-ray spectrometer (SEM/EDS) was used to investigate the submicron particles. With this type of instrument a number of signals, such as secondary electrons (SE), backscattered electrons (BSE) and X-rays, result from the interactions of a focused scanning electron beam with the atoms of a specimen, thus providing different information about the sample.

Table 1. Sample labels, TSS concentrations determined in the field with optical sensors, SC sediment amounts, organic debris, phytoplankton, zooplankton, bacteria and fungi.

\begin{tabular}{|c|c|c|c|c|c|c|c|}
\hline Sample & $\begin{array}{c}\text { TSS (mg/l) } \\
\text { field }\end{array}$ & $\begin{array}{l}\text { SC (mg/l) } \\
\text { laboratory }\end{array}$ & Org. debris (no./ml) & $\begin{array}{l}\text { Phytoplan. } \\
\text { (CFU/ml) }\end{array}$ & $\begin{array}{c}\text { Zooplan. } \\
\text { (no./ml) }\end{array}$ & $\begin{array}{c}\text { Bacteria } \\
\text { (CFU/ml) }\end{array}$ & $\begin{array}{c}\text { Fungi } \\
\text { (CFU/ml) }\end{array}$ \\
\hline D1 & 585 & 260.0 & 80,000 & 100,000 & 1 & $1,000,000$ & 1000 \\
\hline $\mathrm{D} 2$ & 41 & 18.5 & 7000 & 10,000 & 0 & 3000 & 0 \\
\hline D3 ${ }^{*}$ & 8 & 3.9 & 200 & $<600$ & 4 & 500,000 & 800 \\
\hline D4 & 41 & 27.9 & 20,000 & 20,000 & 1 & 2000 & 0 \\
\hline D5 & 33 & 15.4 & 20,000 & 50,000 & 1 & 3000 & 0 \\
\hline $\mathrm{V} 1^{*}$ & 45 & 24.0 & 1000 & $<600$ & 2 & 1000 & 100 \\
\hline $\mathrm{V} 2^{*}$ & 72 & 30.9 & 8000 & $<600$ & 2 & 1000 & 100 \\
\hline V3 & 30 & 18.4 & 5000 & 15,000 & 1 & 50,000 & 5000 \\
\hline V4 & 6 & 21.0 & 2500 & 800 & 20 & $10,000,000$ & 10,000 \\
\hline V5 & 16 & 9.4 & 2500 & 15,000 & 2 & 500,000 & 500 \\
\hline MO1 & 78 & 42.6 & 13,000 & 70,000 & 1 & 10,000 & 100 \\
\hline MO2 & 149 & 77.6 & 30,000 & 80,000 & 3 & 10,000 & 100 \\
\hline MO3 & 753 & 363.0 & 100,000 & 80,000 & 1 & 100,000 & 10,000 \\
\hline $\mathrm{MO4}^{*}$ & 10 & 6.8 & 2000 & $<600$ & 2 & 500,000 & 500 \\
\hline MO5 & 32 & 16.5 & 30,000 & 10,000 & 0 & 2000 & 0 \\
\hline
\end{tabular}

Note: D-location HPP Dravograd, V-location HPP Vuzenica, MO-location HPP Mariborski otok. "Samples used for TSS concentrations particle size distribution relationship. 


\subsection{Microbiological Analyses}

The microbiological analyses, carried out by the Institute for Applied Ecology of Maribor, were able to measure the phytoplankton, zooplankton, bacteria, fungi and organic debris in all 90 samples of water. Binocular microscopes from CETI and Leica were used to determine the phytoplankton, zooplankton and organic debris. During the microscopy $1 \mathrm{ml}$ of water sample was observed at 100×, 400× and 1000× magnification. A counting chamber manufactured by Paul Marienfeld GmbH \& Co KG was used for the counting. Algae and blue-green cyanobacteria were determined using ALGAE-BART ${ }^{\mathrm{TM}}$ biodetectors. To determine the total number of bacteria, different media were used: dipslides VWR Prolabo Total Count and textile plates RIDA ${ }^{\circledR}$ COUNT Total, and to determine the total number of fungi dipslides VWR Prolabo Yeast/Mold and textile plates RIDA ${ }^{\circledR}$ COUNT Yeast/ Mould were used.

\section{Results and Discussion}

\subsection{The Influence of the Microbiological Parameters of the Water on the In-Situ-Measured TSS Concentrations}

The amounts of different micro-organisms and organic debris in the water changed throughout the year, which is understandable since their occurrence is influenced by numerous environmental factors. The amounts of phytoplankton ranged from $>600$ to 100,000 CFU/ml (CFU/ml = Colony Forming Units and $1 \mathrm{ml}$ of water) at all three measuring points. The density of zooplankton, which is expressed by the number of individuals in a given volume of water (no./ml), was between 0 and $30 \mathrm{no} . / \mathrm{ml}$, the density of the bacteria was between 100 and 10,000,000 CFU/ml and the density of the fungi was between 0 and 10,000 CFU/ml. The amount of organic debris varied between 100 and 100,000 no./ml. It was found from the data of the microbiological tests that there was no significant correlation between the amounts of zooplankton, bacteria and fungi in the water and the in-situ-measured TSS concentrations. It can be concluded that these particles have a very low impact on the results of the measurements. In contrast to this, the impact of the phytoplankton and the organic debris could have been higher. It is evident from Figure 3 that their quantities generally increase with increasing TSS concentrations.

\subsection{The Relationship between the In-Situ-Measured TSS Concentrations and the Laboratory-Determined SC}

The concentrations of the in-situ-measured total suspended solids (TSS) reached a maximum of $753 \mathrm{mg} / \mathrm{l}$ (HPP Mariborski otok), although the majority of the values were less than $40 \mathrm{mg} / \mathrm{l}$. The comparison of these values with the quantity of particles settled in standing water SC (mg/l) showed that the variables are linearly correlated at all three measuring points, which was expected. The data collected in the study showed the below relationships for each location: (Equations (2)-(4)).

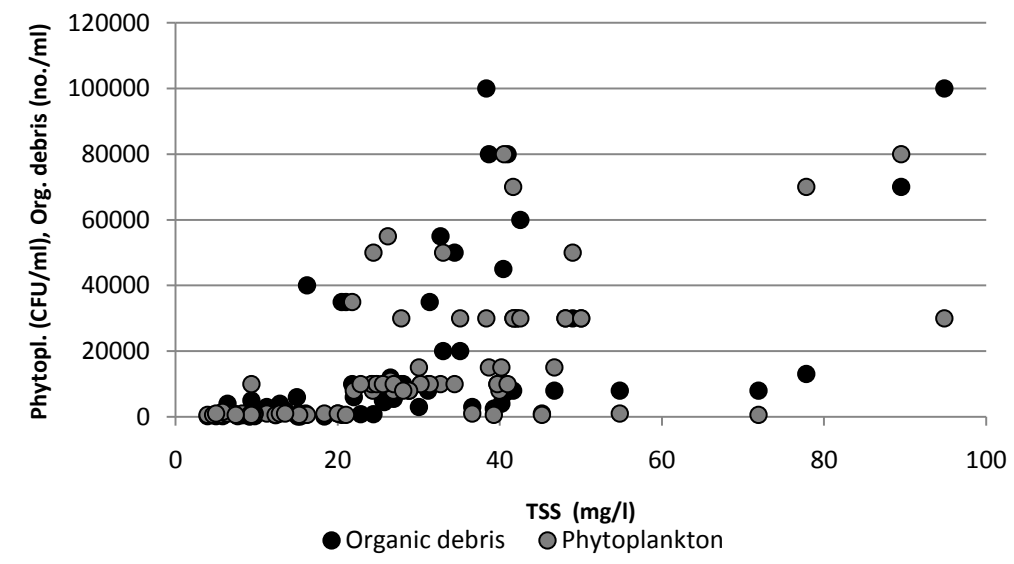

Figure 3. The amounts of phytoplankton (CFU/ml) and organic debris (no./ml) as a function of the in-situ-measured TSS concentrations (mg/l). 


$$
\begin{gathered}
\text { HPP Dravograd } \quad \mathrm{SC}=0.40 \cdot \mathrm{TSS}(\mathrm{mg} / \mathrm{l}) \\
\text { HPP Vuzenica } \\
\text { SC }=0.57 \cdot \mathrm{TSS}(\mathrm{mg} / \mathrm{l}) \\
\text { HPP Mariborski otok } \quad \mathrm{SC}=0.49 \cdot \mathrm{TSS}(\mathrm{mg} / \mathrm{l})
\end{gathered}
$$

An example from HPP Dravograd is presented in Figure 4, where a good correlation is clearly seen between the majority of the measured values. In addition, it was clear that deviations occur in the cases where greater amounts of phytoplankton and organic debris were recorded in water. In these cases, the TSS concentrations in all the samples were higher than expected according to the SC. The influence of the phytoplankton and the organic debris on the TSS concentration was not possible to quantify. The reasons for this are multiple: 1) it was impossible to separate the influence of the phytoplankton from the influence of the organic debris because they appeared simultaneously in increased quantities in the water samples, 2) the type, the size and the shape of the phytoplankton and organic debris change in various conditions, which all affects the measured TSS concentration, 3) the quantification of the micro-organisms and their dead residuals is carried out on very small samples that are not always representative, 4) the procedure for the determination of phytoplankton does not allow a determination of the exact number of planktonic organisms or their colonies.

\subsection{Particle Size Analyses}

Figure 5 shows the particle size distribution for the samples taken at the measuring point HPP Vuzenica. The average TSS concentrations measured at the times when the samples were taken are also marked in Figure 5. From the comparison of these values the correlation between the particle size distributions of the sediments and the TSS concentrations can be clearly seen. In order to determine this relationship, four samples of sediments, labelled D3, V1, V2 and MO4 (basic samples), were selected. All the samples were taken from water containing a small amount of organic debris and phytoplankton (Table 1). Figure 6 shows that the relationship between the percentage of grains $\leq D$ ( $D$ is the diameter of the grains) and the TSS concentrations can be described with the polynomial functions in the form:

$$
\% \text { particles } \leq D(\mu \mathrm{m})=A \cdot \mathrm{TSS}^{2}+B \cdot \mathrm{TSS}+C
$$

and that the values of the parameters $A, B$ and $C$ can be expressed as a function of the size of individual particles (Figures 7-9) with the Equations (6)-(11).

For the particles $\leq D=1-10 \mu \mathrm{m}$

$$
\begin{gathered}
A=-0.001 \cdot D+2.7 \cdot 10^{-3} \\
B=-8.8 \times 10^{-3} \cdot D^{2}+0.232 \cdot D-0.328
\end{gathered}
$$

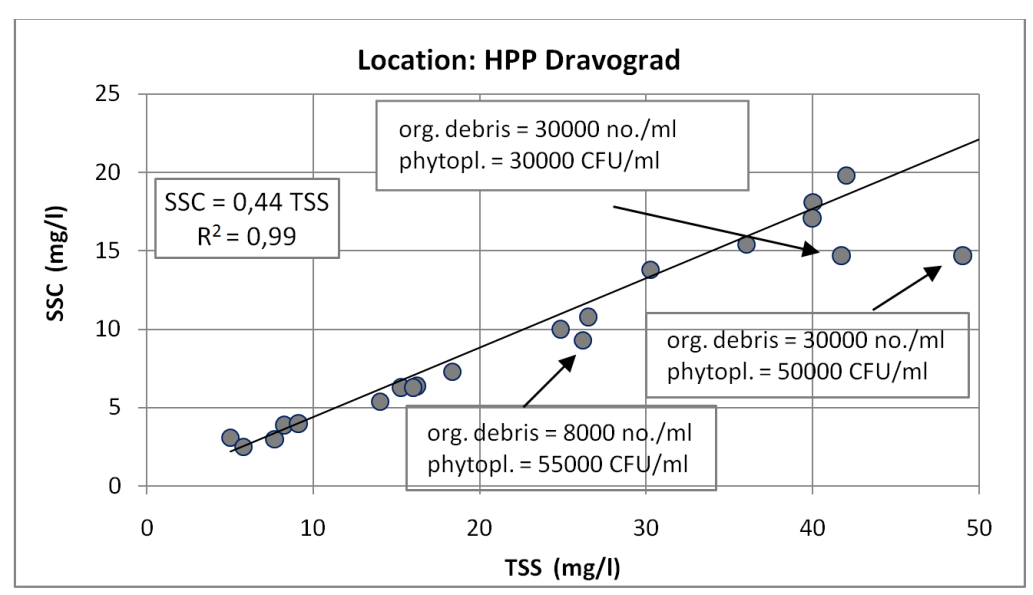

Figure 4. The relationship between the laboratory-determined SC (mg/l) and the in-situ-measured TSS concentrations (mg/l) with optical sensors. 


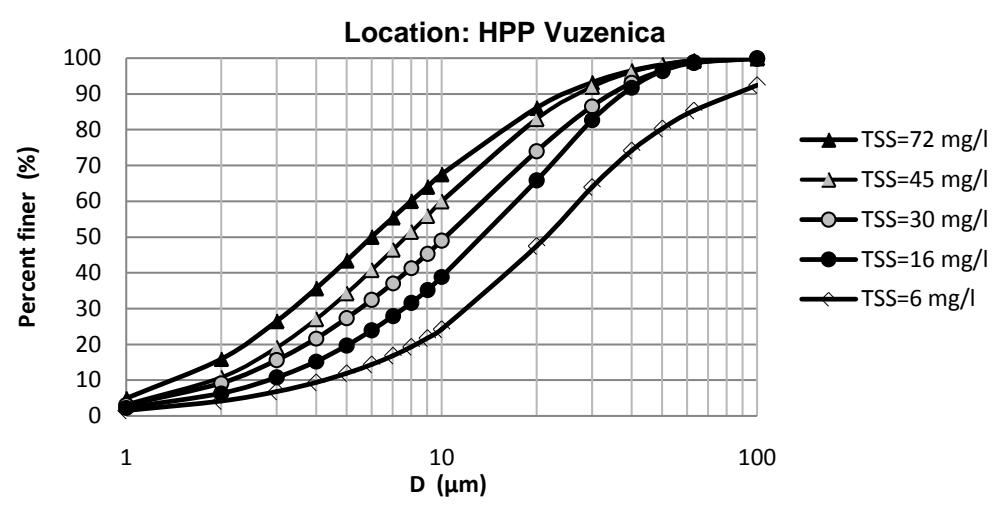

Figure 5. Particle size distribution for the samples from the location of HPP Vuzenica.

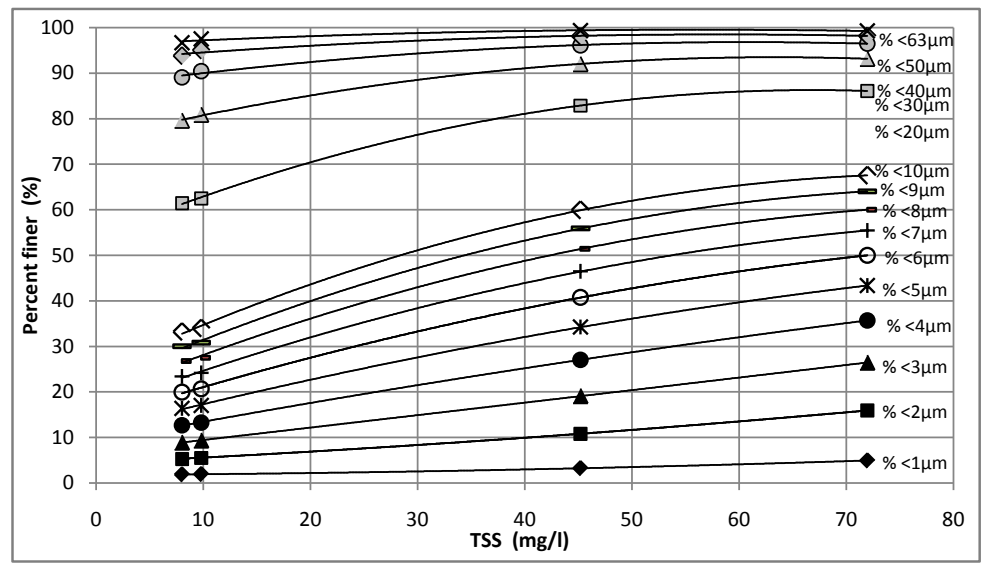

Figure 6. Relationships between the percentages of particles with diameter $D$ $\leq 1 \mu \mathrm{m}$ to $63 \mu \mathrm{m}$ and the in-situ-measured TSS concentrations (mg/l) using optical sensors.

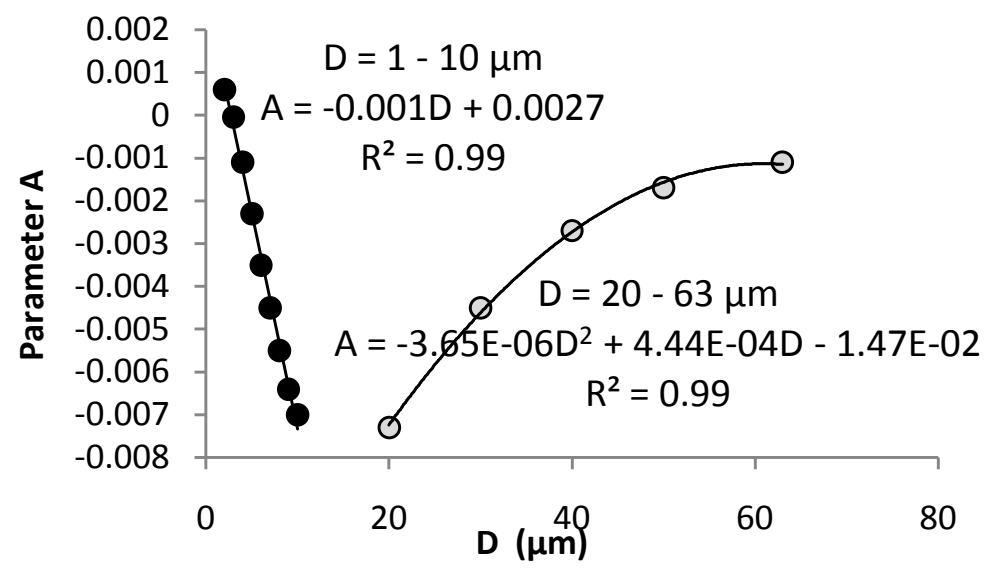

Figure 7. Dependence of parameter $A$ on the particle size $\leq D(\mu \mathrm{m})$.

$$
C=2.52 \times 10^{-2} \cdot D^{2}+2.186 \times D-0.127
$$

for the particles $\leq D=20-63 \mu \mathrm{m}$

$$
A=-3.65 \times 10^{-6} \cdot D^{2}+4.44 \times 10^{-4} \cdot D-1.47 \times 10^{-2}
$$




$$
\begin{aligned}
& B=5.42 \times 10^{-4} \cdot D^{2}-6.43 \times 10^{-2} \cdot D+2.04 \\
& C=-2.90 \cdot 10^{-2} \cdot D^{2}+3.354 \cdot D-0.792
\end{aligned}
$$

The comparisons between the measured values (marked with lines) and calculated values (marked with points) for the basic samples are shown in Figure 10. While in the illustrated cases the calculated values completely

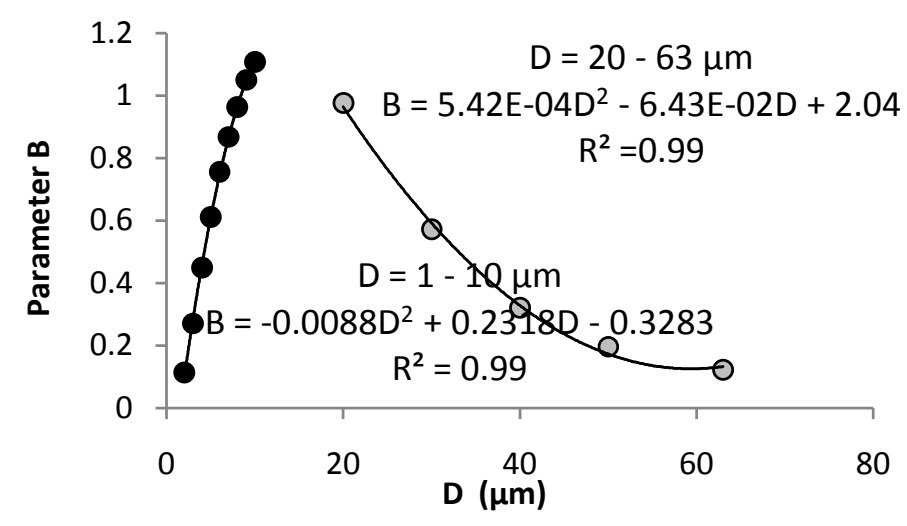

Figure 8. Dependence of parameter $B$ on the particle size $\leq D(\mu \mathrm{m})$.

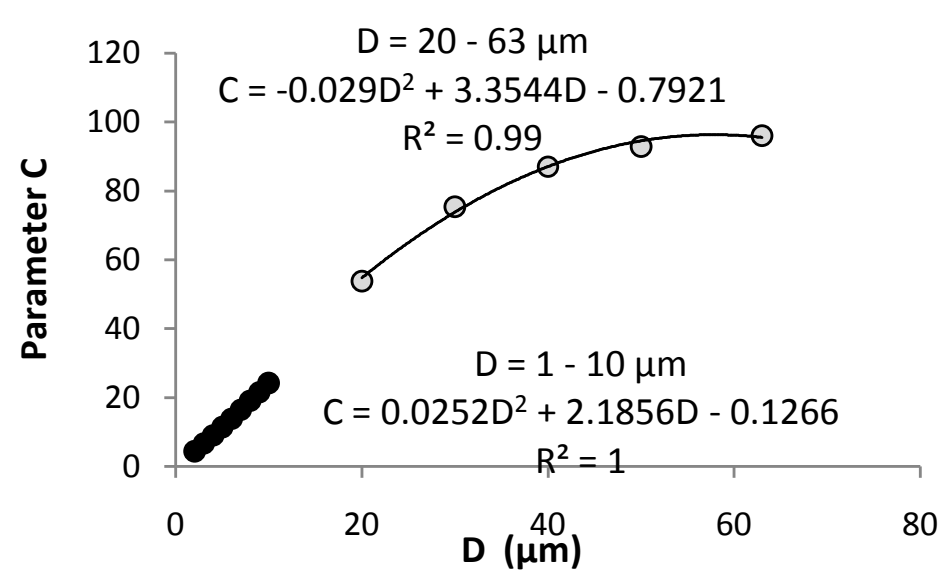

Figure 9. Dependence of parameter $C$ on the particle size $\leq D \quad(\mu \mathrm{m})$.

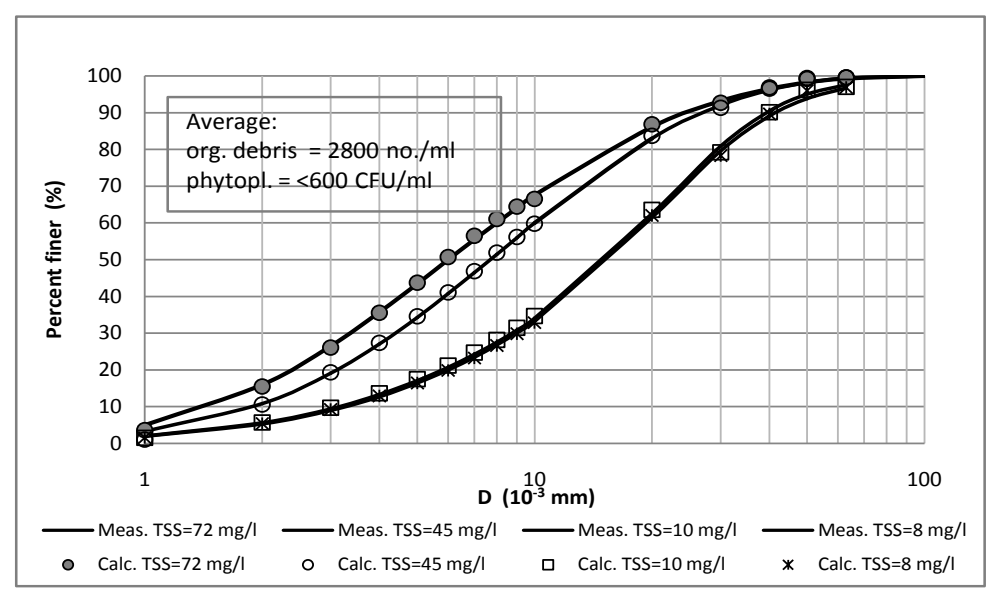

Figure 10. Measured values and values calculated from the results of in-situmeasured TSS concentrations for basic samples. 
correspond to the measured values, this is not true for samples with a large content of phytoplankton and organic debris. These examples are given in Figure 11 and Figure 12, which show that the calculated grading curves are very different compared to those that are actually measured. The differences increase with increasing amounts of organic matter, which points to their large influence on the in-situ-measured TSS concentrations. As a result, these exhibit higher proportions of fine fractions than are actually present in the sediment material.

Figure 13 shows the difference (\%) between the measured portions of grains $\leq D(\mu \mathrm{m})$ and those calculated from the TSS concentrations. The legend marks the amounts of organic debris and phytoplankton in the corresponding water samples. The figure clearly shows that by increasing the amounts of these organic particles the differences between the actual portions of the grains of a certain size and those calculated on the basis of the TSS concentrations increase. The results shown are logical and to be expected because inorganic particles mainly occur in sediments, while in water greater quantities of organic substances are present.

\subsection{Mineralogical Composition}

With the help of the X-ray diffraction analyses and the chemical compositions of the samples, the following qualitative and quantitative mineral compositions of the deposited material were determined: muscovite/illite $(30 \%$ ), chlorite (16\%), quartz (17\%), plagioclase $(4 \%)$, microcline $(4 \%)$, calcite $(6 \%)$, dolomite $(17 \%)$, pirite (3\%) and hematite (3\%). The chemical analyses only showed $2 \%$ of organic substances in sediment.

The optical microscope examination, which was used mainly to analyse particles $>20 \mu \mathrm{m}$, showed that the

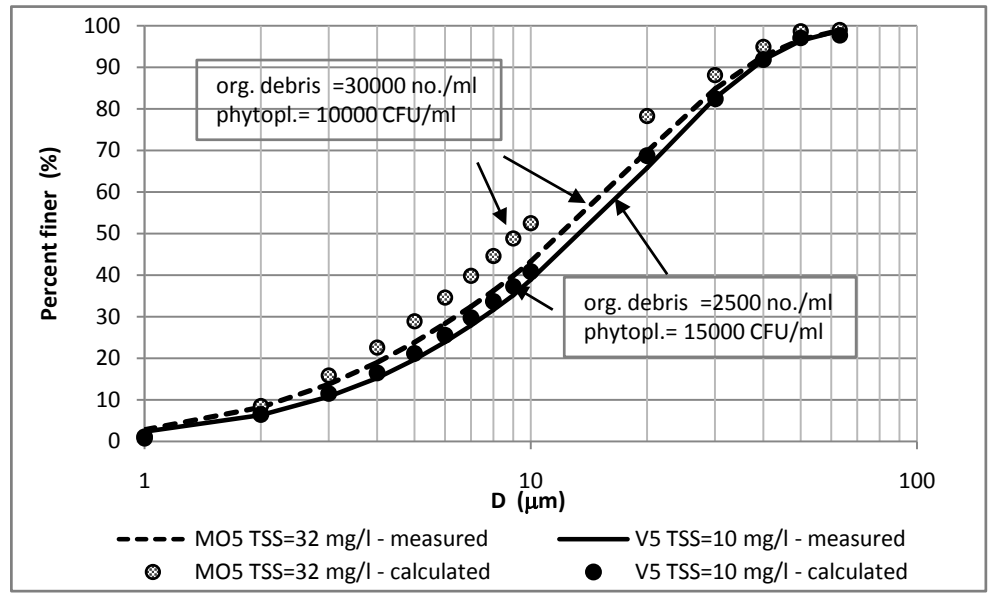

Figure 11. Measured values and values calculated from the results of in-situmeasured TSS concentrations for samples MO5 and V5.

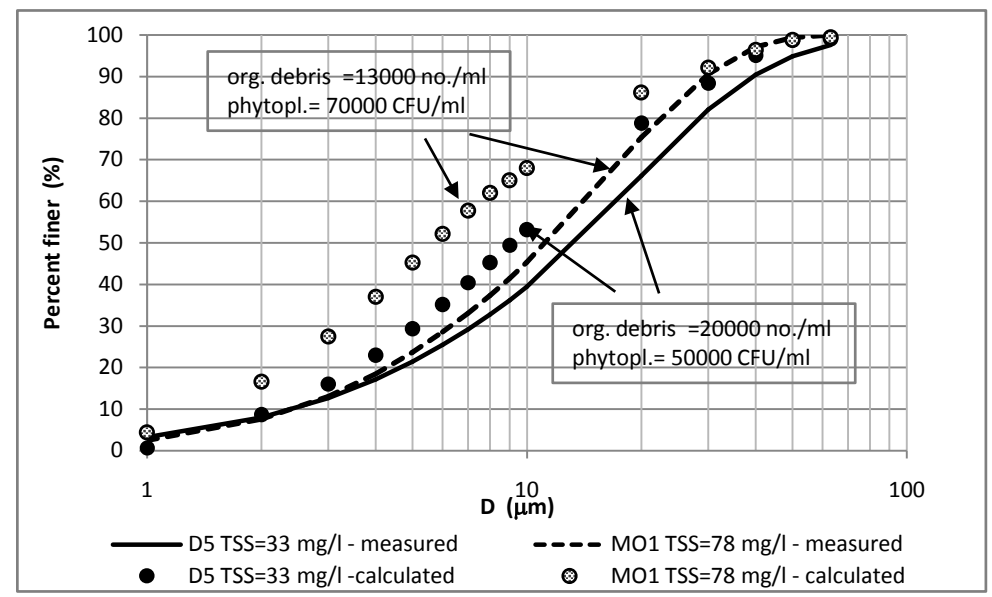

Figure 12. Measured values and values calculated from the results of in-situmeasured TSS concentrations for samples D5 and MO1. 
sample consisted mainly of grains of muscovite, biotite, quartz and feldspars. Among the opaque minerals it was possible to identify limonite (goethite) and traces of hematite. More rarely, there were observations of carbonates and chlorite. Clinozoisite grains could be observed in very small amounts, and there were traces of tourmaline, staurolite, zircon and rutile, as well as residual organic detritus. Figure 14 shows an acicular set with a trapped grain of calcite.

Figure 15 shows photographs of sediment investigated with a scanning electron microscope (SEM/EDS). With the help of secondary electrons (SE), which give an image of the sample surface, and backscattered electrons (BSE), which give an image of the relative chemical composition of the sample, the following mineral phases were determined: muscovite/illite, plagioclase, chlorite, quartz, calcite, amphibole, titanite and green algae.

\section{Conclusions}

This paper presents the results of an investigation whose purpose was to determine the possibility of using in-situ-measured total suspended solids (TSS) concentrations to determine the amount and the size of the grains for that part of the suspended solids in the Drava River that can settle in standing water. The correlation was made for the purposes of forecasting the amount of sediments in the accumulation basin of the planned

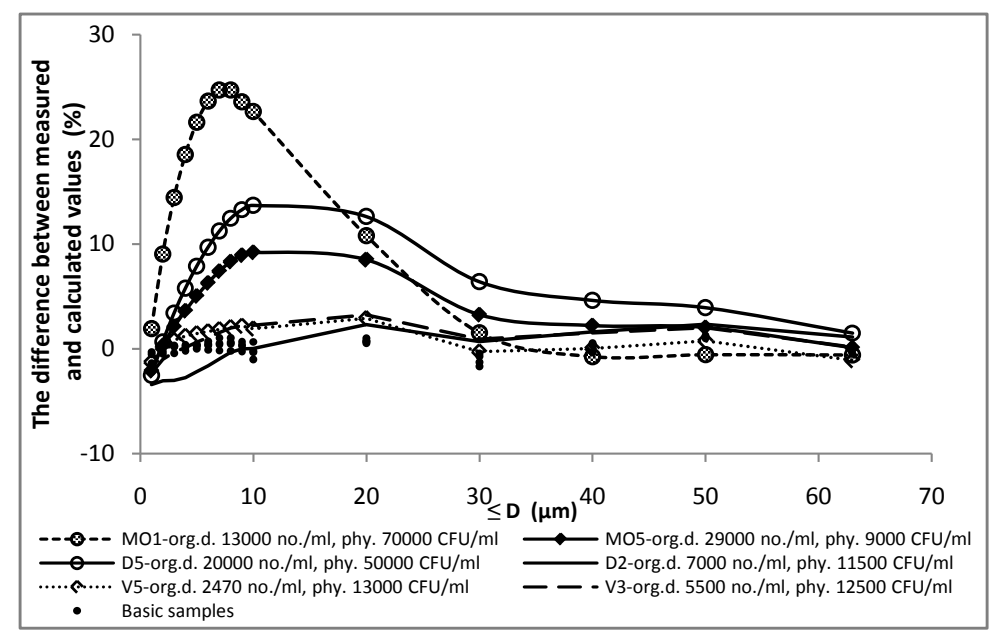

Figure 13. The difference (\%) between the measured and calculated portions of particles $\leq D(\mu \mathrm{m})$.

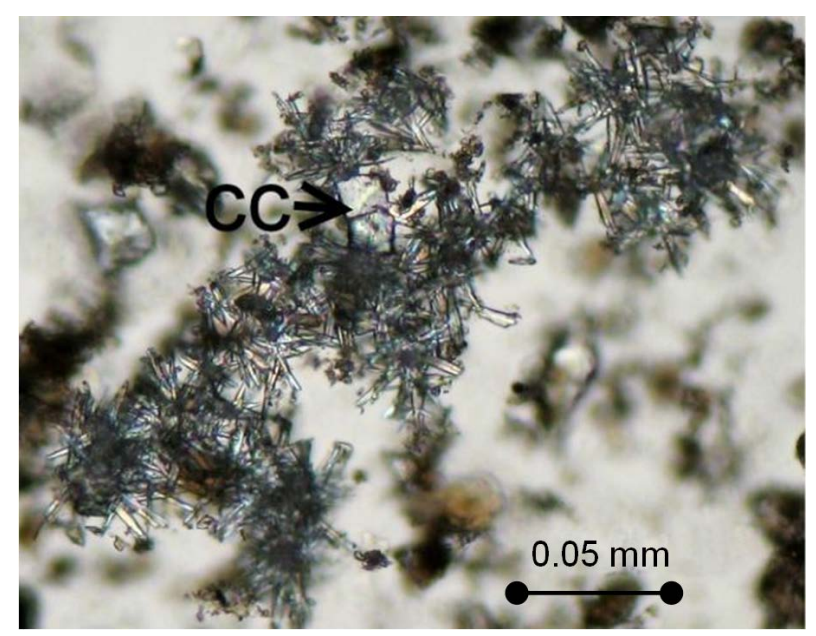

Figure 14. An acicular set similar to cellulose with a trapped grain of calcite (cc), II N. 

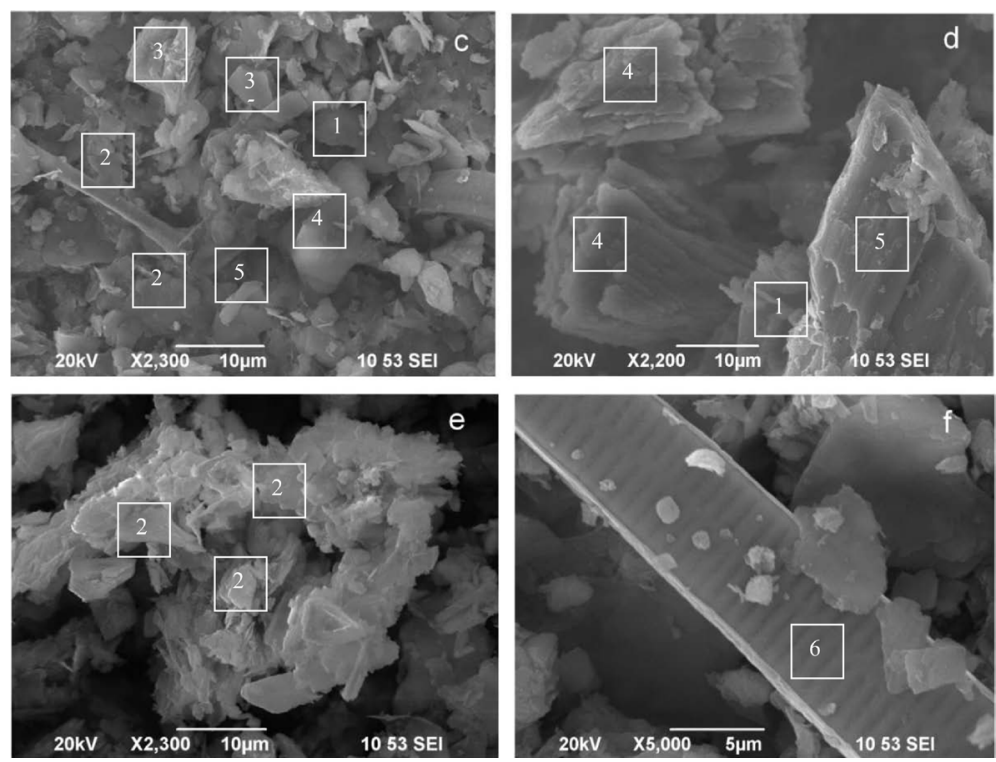

Figure 15. SEM micrographs of particle sediments: 1-chlorite, 2-biotite /chlorite, 3-quartz, 4-calcite, 5-amphibole and 6-green algae.

pumped-storage hydroelectric power plant Kozjak. Water from the Drava River will be pumped into the basin from the anticipated pumping station that will be located between the HPP Vuzenica and the HPP Mariborski otok, where two of three optical sensors were installed for continuous monitoring of the TSS concentrations in the Drava River.

The investigations showed that on the basis of in-situ-measured TSS concentrations using optical sensors in the Drava River a good estimate is possible for the amounts of those suspended solids that can settle in standing water. In the investigated cases, these volumes were approximately $50 \%$ lower than those that were measured. It was also possible to define, very accurately, the particle size distribution in the sediments. The above arguments apply to most of the test samples; however, deviations occur in the cases of increased amounts of phytoplankton and organic debris in the water. In these cases, the in-situ-measured TSS concentrations show higher values than expected with respect to the analytical results from the samples. An effect of the zooplankton, bacteria, fungi, temperature and $\mathrm{pH}$ value of the water on the TSS concentrations was not observed.

\section{Acknowledgements}

The authors express their thanks to Dravske elektrarne Maribor for financing the research presented in this article and for providing assistance in obtaining the data.

\section{References}

[1] Al-Yaseri, I., Morgan, S. and Retzlaff, W. (2013) Using Turbidity to Determine Total Suspended Solids in StormWater Runoff from Green Roofs. Journal of Environmental Engineering, 139, 822-828. http://dx.doi.org/10.1061/(ASCE)EE.1943-7870.0000685

[2] Branigan, J. (2013) Development of a Field Test for Total Suspended Solids Analysis. Civil Engineering Theses, Dissertations, and Student Research, University of Nebraska, Lincoln, 68. http://digitalcommons.unl.edu/civilengdiss

[3] Gray, J.R. and Gartner, J.W. (2009) Technological Advances in Suspended-Sediment Surrogate Monitoring. Water Resources Research, 45, 1-20. http://dx.doi.lorg/10.1029/2008WR007063

[4] Guillen, J., Palanques, J., Puig, P., Durrieu de Madron, X. and Nyffeler, F. (2000) Field Calibration of Optical Sensors for Measuring Suspended Sediment Concentration in the Western Mediterranean. Scientia Marina, 64, 427-435.

[5] Landers, M. N. and Sturm, T.W. (2013) Hysteresis in Suspended Sediment to Turbidity Relations Due to Changing Particle Size Distributions. Water Resources Research, 49, 5487-5500. http://dx.doi.org/10.1002/wrcr.20394

[6] Susfalk, R.B., Fitzgerald, B. and Knust, A.M. (2008) Characterization of Turbidity and Total Suspended Solids in the 
Upper Carson River, Nevada. DHS Publication No. 41242.

[7] Williamson, T.N. and Crawford, C.G. (2011) Estimation of Suspended-Sediment Concentration from Total Suspended Solids and Turbidity Data for Kentucky, 1978-1995. Journal of the American Water Resources Association (JAWRA), 47, 739-749. http://dx.doi.org/10.1111/j.1752-1688.2011.00538.x

[8] DEM (2014) Projekt ČHE Kozjak. http://www.dem.si/slo/razvojnemoznostidem/crpalnahenadravi

[9] Mikoš, M. (2012) Metode terenskih meritev suspendiranih sedimentov v rekah (Methods of Field Measurements of Suspended Sediments in Rivers). Gradbeni Vestnik, 61, 151-158. 